Egyptian Journal of Aquatic Biology \& Fisheries

Zoology Department, Faculty of Science,

Ain Shams University, Cairo, Egypt.

ISSN $1110-6131$

Vol. 24(2): 163 - 175 (2020)

www.ejabf.journals.ekb.eg

\title{
On some factors affecting molting and growth rate of the giant freshwater prawn,
} Macrobrachium rosenbergii (De Man, 1879)

\section{Madlen M. Habashy ${ }^{1, *}$ and Khadiga M. Sharshar ${ }^{2}$}

1;National Institute of Oceanography and Fisheries, Egypt.

2;Zoology department, Faculty of Science, Tanta University. Tanta, Egypt.

Corresponding Author: madlinhabashy@yahoo.com

\begin{abstract}
ARTICLE INFO
Article History:

Received: July 14, 2019

Accepted: March 22, 2020

Online: March 27, 2020
\end{abstract}

\section{Keywords:}

Freshwater prawn

Macrobrachium rosenbergii

Temperature,

Photoperiod,

Molting,

\begin{abstract}
The effect of temperature $\left(20,25,30\right.$ and $\left.35^{\circ} \mathrm{C}\right)$, salinity $(0,5,10$ and 15 ppt), pH (6, 7, 8 and 9) and light (24h L:00hD, 12hL:12hD and 00hL:24hD) on molting cycle, growth and survival of larvae of the freshwater prawn Macrobrachium rosenbergii were investigated independently under laboratory conditions. Temperature, salinity and $\mathrm{pH}$ significantly $(\mathrm{P}<0.05)$ influenced the molting, growth and survival of the prawns. The influence of photoperiod was not significant $(\mathrm{P}>0.05)$. The best levels of temperature, salinity and $\mathrm{pH}$, which gave the fast molt with the highest growth increment in $M$. rosenbergii were $30^{\circ} \mathrm{C}, 5 \mathrm{ppt}$, and $\mathrm{pH} 8$, respectively. Outside these levels, more molting did not produce more growth. These results have direct implications in the aquaculture production of Macrobrachium rosenbergii and accelerate growth rate of prawns in conditions of intensive culturing with a reduction in production costs.
\end{abstract}

\section{INTRODUCTION}

The giant freshwater prawn, Macrobrachium rosenbergii is a common inhabitant in rivser and in estuaries throughout the Indo-Pacific regions. This species is of commercial importance for food due to its fast growth in subtropical and tropical regions, New(1995). Molting in crustacean is only a part of the mechanism of growth. Change in form and increase in size can occur when the hard calcareous exoskeleton is shed and before the new cuticle is hardened Venkitraman et al. (2010). The environment of the region, where the species is farmed is often subjected to rapid and wide fluctuations in environmental factors. Prawns move in space and time through these biotic factors, including temperature, salinity, $\mathrm{pH}$ and light, which significantly influence their molting and 
growth process ( Aiken, 1980; Boyed, 1990 and Dall et al,1990). Knowledge about the growth pattern and molting of a particular species to different levels of environmental variables could serve as a reliable indicator of its environmental limitations as a potential aquaculture species. Molting frequency and size increase may be influenced independently by changes in environmental conditions, hence to best determine growth rate of prawns, both molting frequency and growth over the period need to measured. In freshwater ponds, $\mathrm{pH}$ levels fluctuate from 6.6 to 10.2 because of the removal of carbon dioxide due to photosynthesis by plants during daytime and release carbon dioxide by both plants and animals during night Boyd(1990).

Macrobrachium rosenbergii can be reared at temperature ranging from 14 to $35^{\circ} \mathrm{C}$ and the optimal temperature and $\mathrm{pH}$ range is $29-31^{\circ} \mathrm{C}$ and $7.0-8.5$, respectively New (1995). This species inhabits in both freshwater and low salinity water. M. rosenbergii is a typical palaemonid which spawns and develops in brackish water, and following metamorphosis, the postlarvae move upstream towards freshwater (Chen and Kou 1996). In the present study, the independent influence of selected environmental factors, temperature salinity, $\mathrm{pH}$ and light on molt cycle duration and growth of the freshwater prawn M. rosenbergii under laboratory conditions. Objectives of the study were:(1) to determine the optimum environmental regime in which growth is highest, (2) To study the environmental influence on molting frequency, (3) to test the hypothesis "more molting means more growth".

\section{MATERIALS AND METHODS}

Experiments were conducted at Invertebrates Laboratory Fish Research Station, at ElQanater El-Khairya, Egypt. Larvae of M. rosenbergii were purchased from Maruit Fish Farming Company at Alexandria ( El-Amria region). They were sorted in four experimental groups to test the impact of temperature, salinity, $\mathrm{pH}$ and light on growth rate and molting process. The details are given in Table 1. Prawns were allowed to acclimate to the selected treatment of temperature, salinity, $\mathrm{pH}$ and light for 7 days prior to experiment initiation. Separate animals were used for the different experiments. Prawns were held individually in glass aquaria $(20 \times 20 \times 20 \mathrm{~cm})$ filled with 5 -L test solutions to examine the growth and molting of each prawn. Each aquarium was aerated by air electric pump. At the start and end of each experiment, prawns were blotted dry and weighed in electronic balance . Total length (from the tip of rostrum to tip of telson) was measured using a vernier caliper. Prawns were fed twice daily in the morning and evening on a pelletized shrimp feed (35\% crude protein, 15 crude lipid, 7.8 ash), feeding level 3\% of body weight. Presence of exuvia indicated the event of molt. Every morning, each aquarium, was checked to record molting. Molt cycle duration was expressed as average time between successive molts of each prawn during the experimental period of 60 days. 
Molt cycle duration of individual prawn $(h)=$ Total time duration of the completed molt cycles(h)/Number of molts (Vljayan and Diwan 1995).

Three-fourth of the medium was replaced once daily. Growth was recorded as the length and weight gain during the experimental period.

Increment in length $=$ Final length $(\mathrm{cm})$-Initial length $(\mathrm{cm})$

Increment in weight $=$ Final weight $(\mathrm{g})-$ Initial weight $(\mathrm{g})$

\section{Temperature}

Temperature levels selected for the experiment are given in Table 1. Four separate water bath were used at a time for the four different treatments. Groups of 20 prawns (1.5 $\mathrm{cm}$ initial length, $0.03 \mathrm{~g}$. initial wet weight), were Kept individually in small glass aquaria, were arranged in each water bath set at temperatures of $20,25,30$ and $35^{\circ} \mathrm{C}$ with a temperature control unit comprising a submersible heater regulated by a thermostat. The temperature of the water bath was made uniform by continuous stirring and bubbling. Parameters other than the experimental ones were maintained at a constant level during the experiment (Table1).

\section{Salinity}

Prawns of $1.7 \mathrm{~cm}$ initial length, $0.04 \mathrm{~g}$ initial wet weight were used in this experiment. Selected salinities for the study are given in (Table 1). Test salinities were prepared by diluting seawater with stored and aerated tap water. Salinity was measured and adjusted by using a Salinity-Conductivity-Temperature Meter (YSI Model 33) . During the salinity experiment other parameters were kept constant.

\section{The pH values}

The initial length of prawns used in this experiment was $2.00 \mathrm{~cm}$ and the initial weight was $0.06 \mathrm{~g}$. Different $\mathrm{pH}$ media levels (Table 1) were prepared in a $250 \mathrm{~L}$ plastic tanks, and kept at least 3 days to stabilize. Every day $\mathrm{pH}$ was adjusted to the required level. Media for lower ranges of $\mathrm{pH}$ were prepared by using $1 \mathrm{~N} \mathrm{HCL}$, and higher ranges were prepared by using $1 \mathrm{~N} \mathrm{NaOH}$ solution. Air stones were not used for aeration purposes to avoid their possible interaction with $\mathrm{pH}$ media; instead aeration was given directly through plastic aeration tubes. The $\mathrm{pH}$ was checked at 24-h intervals; and variation from the desired $\mathrm{pH}$ levels was compensated by adding acid or alkali. $\mathrm{pH}$ was adjusted with digital pH Meter (ML1010). During the experiment, parameters other than $\mathrm{pH}$ were kept constant. 


\section{Light}

Prawns of initial length $1.7 \mathrm{~cm}$ and weight of $0.04 \mathrm{~g}$. were used in this experiment. The three light regimes selected for the experiment are given in Table 1. The circular photoperiodic chamber made of rigid PVC sheet $(100 \times 80 \mathrm{~cm})$ was covered with black canvas. A $40 \mathrm{~W}$ daylight fluorescent bulb produce mean illumination of 400-600 Lux at the water surface in the chamber during the light phase, and light was cut off during dark phase. The light periods were set by standard time switches. Other parameters were maintained at constant levels (Table 1).

\section{Statistical analysis}

Mean and standard deviation were calculated from the experimental data. The significance of the difference among the treatments under each experiment was tested using one-way analysis of variance (ANOVA). The comparison of individual means of different treatments was made using the Student Neuman-Keuls multiple range test Zar (1984).

Table 1. Experimental design used to test the effects of temperature, $\mathrm{pH}$, salinity and light on molting and growth of $M$. rosenbergii

\begin{tabular}{lllll}
\hline Parameters & Temperature ${ }^{\circ} \mathrm{C}$ & Salinity (ppt) & $\mathrm{pH}$ & Light/Dark \\
\hline $\begin{array}{l}\text { Croup 1 in relation } \\
\text { to temperature }\end{array}$ & 20 & 5 & 8 & $12 \mathrm{hL}: 12 \mathrm{hD}$ \\
$(\mathrm{n}=20)$ & 30 & & & \\
& 35 & 0 & 8 & $12 \mathrm{hL}: 12 \mathrm{hD}$ \\
\hline $\begin{array}{l}\text { Group 2 in relation } \\
\text { to salinity (n=20) }\end{array}$ & 30 & 5 & & \\
& & 10 & 6 & $12 \mathrm{hL}: 12 \mathrm{hD}$ \\
\hline $\begin{array}{l}\text { Group 3 in relation } \\
\text { to pH (n=20) }\end{array}$ & 30 & 5 & 8 & \\
& & & 9 & $24 \mathrm{hL}: 00 \mathrm{hD}$ \\
& & 5 & 8 & $12 \mathrm{hL}: 12 \mathrm{hD}$ \\
\hline $\begin{array}{l}\text { Group 4 in relation } \\
\text { to light (n=20) }\end{array}$ & 30 & & & $00 \mathrm{hL}: 24 \mathrm{hD}$ \\
\hline
\end{tabular}

\section{RESULTS}

\section{Temperature}

Higher temperature levels were found to accelerate the molt cycle and growth of $M$. rosenbergii (Table 2). The longest molt cycle duration of $125 \pm 8 \mathrm{~h}$ was recorded at $20{ }^{\circ} \mathrm{C}$. At temperature of 25 and $30^{\circ} \mathrm{C}$, molts occurred at faster rate with reduced molt cycle 
duration of 100 and $96 \mathrm{~h}$, respectively. The shortest molt cycle of $53 \mathrm{~h}$ was recorded among prawns exposed to $35^{\circ} \mathrm{C}$. But the fast molt cycle, coupled with a corresponding growth gain in terms of length and weight, was observed only up to temperature of $30^{\circ} \mathrm{C}$. Above $30^{\circ} \mathrm{C}$, the molt cycle was faster but did not produce much increase in length or weight.

A maximum gain in both length and wet weight $(6.5 \mathrm{~cm}$ and $4.93 \mathrm{~g})$ was recorded at 30 ${ }^{\circ} \mathrm{C}$, which significantly differ than growth of prawns at the other ranges of temperature $(\mathrm{P}<0.05)$. The lowest growth in terms of length and weight was recorded at the highest temperature of $35^{\circ} \mathrm{C}$. The highest survival rate was observed at both temperatures of 25 and $30{ }^{\circ} \mathrm{C}$ which represented by 91 and $90 \%$, respectively. While the lowest survival (59\%) was found at $35^{\circ} \mathrm{C}$. When duration of molt was considered with growth increment, the most favorable temperature observed was $30^{\circ} \mathrm{C}$. ANOVA showed a significant difference $(\mathrm{P}<0.05)$ in molting period, growth and survival due to temperature range.

Table 2: Effects of temperature on molting, growth and survival of $M$. rosenbergii larvae (Mean \pm SD)

\begin{tabular}{|c|c|c|c|c|}
\hline \multirow[t]{2}{*}{ Parameters } & \multicolumn{4}{|c|}{ Temperature $\left({ }^{\circ} \mathrm{C}\right)$} \\
\hline & 20 & 25 & 30 & 35 \\
\hline Initial length $(\mathrm{cm})$ & $1.50 \pm 0.277^{\mathrm{a}}$ & $1.50 \pm 0.277^{\mathrm{a}}$ & $1.50 \pm 0.277^{\mathrm{a}}$ & $1.50 \pm 0.277^{\mathrm{a}}$ \\
\hline Initial weight (g) & $0.03 \pm 0.010^{\mathrm{a}}$ & $0.03 \pm 0.01^{\mathrm{a}}$ & $0.03 \pm 0.01^{\mathrm{a}}$ & $0.03 \pm 0.01^{\mathrm{a}}$ \\
\hline Final length $(\mathrm{cm})$ & $4.70 \pm 0.628^{b}$ & $6.00 \pm 0.910^{\mathrm{b}}$ & $8.00 \pm 1.561^{\mathrm{a}}$ & $5.50 \pm 1.208^{\mathrm{b}}$ \\
\hline Final weight (g) & $0.91 \pm 0.0211^{\mathrm{c}}$ & $2.02 \pm 0.612^{\mathrm{b}}$ & $4.96 \pm 0.75^{\mathrm{a}}$ & $1.48 \pm 0.968^{\mathrm{c}}$ \\
\hline Increase in length $(\mathrm{cm})$ & $3.20 \pm 0.098^{\mathrm{c}}$ & $4.50 \pm 1.031^{\mathrm{b}}$ & $6.50 \pm 1.75^{\mathrm{a}}$ & $4.00 \pm 0.855^{\mathrm{c}}$ \\
\hline Increase in weight $(\mathrm{g})$ & $0.88 \pm 0.252^{\mathrm{c}}$ & $1.99 \pm 0.421^{\mathrm{b}}$ & $4.93 \pm 1.51^{\mathrm{a}}$ & $1.45 \pm 0.652^{b}$ \\
\hline Molt cycle duration (h) & $125 \pm 8.000^{\mathrm{a}}$ & $100 \pm 11.40^{\mathrm{a}}$ & $96 \pm 10.60^{\mathrm{a}}$ & $53 \pm 6.70^{b}$ \\
\hline Survival (\%) & $85 \pm 12.20^{\mathrm{a}}$ & $91 \pm 10.80^{\mathrm{a}}$ & $90 \pm 7.56^{\mathrm{a}}$ & $59 \pm 8.55^{\mathrm{b}}$ \\
\hline
\end{tabular}

Means bearing different superscript in same row the are significantly different $(\mathrm{P}<0.05)$.

\section{Salinity}

The shortest molt cycle duration $(130 \mathrm{~h})$ were recorded at both salinities of 0 and $5 \mathrm{ppt}$. Results revealed that as salinity increase the molt cycle duration increase and growth in terms of length and weight decrease, so the maximum gain in length and weight was recorded at the lowest salinities( 0 and 5 ppt). While the lowest gain in both length and weight of prawns was found at 10 and 15 ppt salinities, where the molt cycle duration was represented by 145 and $179 \mathrm{~h}$, respectively. It was noted that the animals exposed to 15 ppt salinities developed some muscle necrosis.

In terms of length and weight, the highest growth increment 0 f $7.1 \mathrm{~cm}$ and $5.21 \mathrm{~g}$ was recorded among the prawn exposed to $5 \mathrm{ppt}$ followed by those exposed to zero salinity with a length gain of $4.9 \mathrm{~cm}$ and wet weight gain of $4.06 \mathrm{~g}$. At the highest experimental 
salinity ( $15 \mathrm{ppt}$ ), length and weight gain recorded were lowest, $2.8 \mathrm{~cm}$ and $0.72 \mathrm{~g}$, respectively. The highest survival rate $(82 \%)$ was recorded at 5 ppt salinity which differ significantly $(\mathrm{P}<0.05)$ than other treatment. While the lowest significant survival rate (37\%) was recorded at the highest salinity. Table 3. showed Significant changes in the molt cycle duration, growth and survival of the prawns subjected to different salinity levels $(\mathrm{P}<0.05$, Table 3$)$

Table 3: Effects of salinity on molting, growth and survival of $M$. rosenbergii larvae (Mean $\pm \mathrm{SD})$.

\begin{tabular}{lllll}
\hline Parameters & Salinity \%o & & \\
\cline { 2 - 5 } & 0 & 5 & 10 & 15 \\
\hline Initial length $(\mathrm{cm})$ & $1.70 \pm 0.255^{\mathrm{a}}$ & $1.70 \pm 0.255^{\mathrm{a}}$ & $1.70 \pm 0.255^{\mathrm{a}}$ & $1.7 \pm 0.255^{\mathrm{a}}$ \\
Initial weight $(\mathrm{g})$ & $0.04 \pm 0.042^{\mathrm{a}}$ & $0.04 \pm 0.042^{\mathrm{a}}$ & $0.04 \pm 0.042^{\mathrm{a}}$ & $0.04 \pm 0.042^{\mathrm{a}}$ \\
Final length(cm) & $6.60 \pm 1.58^{\mathrm{b}}$ & $8.80 \pm 1.95^{\mathrm{a}}$ & $5.20 \pm 1.98 \mathrm{~b}^{\mathrm{c}}$ & $4.5 \pm 1.25^{\mathrm{c}}$ \\
Final weight (g) & $4.10 \pm 0.98^{\mathrm{b}}$ & $5.25 \pm 1.63^{\mathrm{a}}$ & $1.55 \pm 0.215^{\mathrm{c}}$ & $0.76 \pm 0.175^{\mathrm{d}}$ \\
Increase in length (cm) & $4.90 \pm 1.25^{\mathrm{b}}$ & $7.10 \pm 1.955^{\mathrm{a}}$ & $3.50 \pm 0.984 \mathrm{~b}^{\mathrm{c}}$ & $2.80 \pm 0.655^{\mathrm{c}}$ \\
Increase in weight (g) & $4.06 \pm 1.24^{\mathrm{a}}$ & $5.21 \pm 1.65^{\mathrm{a}}$ & $1.51 \pm 0.379^{\mathrm{b}}$ & $0.72 \pm 0.20^{\mathrm{b}}$ \\
Molt cycle duration (h) & $130 \pm 22.5^{\mathrm{a}}$ & $130 \pm 15.8^{\mathrm{a}}$ & $145 \pm 31.4^{\mathrm{a}}$ & $179 \pm 33.85^{\mathrm{b}}$ \\
& & & & \\
Survival (\%) & $71 \pm 13.5^{\mathrm{a}}$ & $82 \pm 18.75^{\mathrm{a}}$ & $55 \pm 14.9^{\mathrm{b}}$ & $37 \pm 7.55^{\mathrm{b}}$
\end{tabular}

Means bearing different superscript in the same row are significantly different $(\mathrm{P}<0.05)$.

\section{The $\mathbf{p H}$ values}

Prawns exposed to pH 6 and 9 were very weak and their feeding was poor. Abnormal swimming pattern and muscle necrosis were common in these animals. The dead animals were found in half exuviated condition. At $\mathrm{pH} 7$ and 8 all experimental animals molted successfully and were healthy and active with good feed intake. The fastest molt cycle duration of prawn ( $90 \mathrm{~h}$ ) was recorded at $\mathrm{pH} \mathrm{7,} \mathrm{followed} \mathrm{by} \mathrm{those} \mathrm{exposed} \mathrm{to} \mathrm{pH} 8,98 \mathrm{~h}$ which differ significantly $(\mathrm{P}<0.05)$ than the other treatments. The longest molt cycle duration $(190 \mathrm{~h}$ ) was observed for prawn exposed to $\mathrm{pH} 9$ followed by those reared in $\mathrm{pH}$ 6 which represented by 155 h.( Table 4$)$.

The maximum length increment of $5.8 \mathrm{~cm}$ and weight increment of $4.75 \mathrm{~g}$ was recorded in prawns exposed to $\mathrm{pH} 8$, while the lowest length and weight increments of $2.8 \mathrm{~cm}$ and $0.93 \mathrm{~g}$, respectively, were noted among the prawns kept at $\mathrm{pH}$ 6. Although the prawns exposed to $\mathrm{pH} 7$ underwent normal and fast molting, growth attained was considerably lower than that of prawns exposed to $\mathrm{pH} 8$. Fast molt cycle duration which accompanied with the highest growth, in terms of length and weight was obtained at $\mathrm{pH} 8$.

At acidic $\mathrm{pH}(6 \pm 0.3), 57 \%$ of the prawns did not survive along the experimental period of 60 days. The highest survival rate was found for prawn exposed to $\mathrm{pH} 8$, followed by those reared at $\mathrm{pH} 7$, represented by 82 and $80 \%$, respectively. While survival rates were 43 and $61 \%$ for prawns exposed to $\mathrm{pH} 6$ and 9, respectively. Prawns exposed to different 
$\mathrm{pH}$ levels showed significant variation in molt cycle duration, growth and survival rates $(\mathrm{P}<0.05)$.

Table 4: Effects of $\mathrm{pH}$ on molting, growth and survival of $M$. rosenbergii larvae (Mean $\pm \mathrm{SD}$ ).

\begin{tabular}{|c|c|c|c|c|}
\hline \multirow[t]{2}{*}{ Parameters } & \multicolumn{4}{|l|}{ pH } \\
\hline & $6 \pm 0.3$ & $7 \pm 0.05$ & $8 \pm 0.07$ & $9 \pm 0.03$ \\
\hline Initial length $(\mathrm{cm})$ & $2.00 \pm 0.361^{\mathrm{a}}$ & $2.00 \pm 0.361^{\mathrm{a}}$ & $2.00 \pm 0.361^{\mathrm{a}}$ & $2.00 \pm 0.361^{\mathrm{a}}$ \\
\hline Initial weight (g) & $0.06 \pm 0.016^{\mathrm{b}}$ & $0.06 \pm 0.016^{\mathrm{b}}$ & $0.06 \pm 0.016^{\mathrm{b}}$ & $0.06 \pm 0.016^{\mathrm{b}}$ \\
\hline Final length $(\mathrm{cm})$ & $4.80 \pm 1.32^{\mathrm{b}}$ & $6.80 \pm 1.85^{\mathrm{a}}$ & $7.80 \pm 1.99^{\mathrm{a}}$ & $5.10 \pm 1.54^{\mathrm{b}}$ \\
\hline Final weight (g) & $0.99 \pm 0.231^{\mathrm{c}}$ & $2.68 \pm 0.357^{\mathrm{b}}$ & $4.81 \pm 0.989^{\mathrm{a}}$ & $1.96 \pm 0.32 b^{c}$ \\
\hline Increase in length $(\mathrm{cm})$ & $2.80 \pm 0.255^{\mathrm{b}}$ & $4.80 \pm 1.02^{\mathrm{a}}$ & $5.80 \pm 1.22^{\mathrm{a}}$ & $3.10 \pm 0.454^{\mathrm{b}}$ \\
\hline Increase in weight (g) & $0.93 \pm 0.22^{\mathrm{d}}$ & $2.62 \pm 0.886^{\mathrm{b}}$ & $4.75 \pm 1.08^{\mathrm{a}}$ & $1.90 \pm 0.355^{\mathrm{c}}$ \\
\hline Molt cycle duration (h) & $155 \pm 28.5^{\mathrm{a}}$ & $80 \pm 15.00^{\mathrm{b}}$ & $98 \pm 20.3^{\mathrm{b}}$ & $190 \pm 22.7^{\mathrm{a}}$ \\
\hline Survival $(\%)$ & $43 \pm 5.50^{\mathrm{b}}$ & $80 \pm 16^{\mathrm{a}}$ & $82 \pm 16.9^{a}$ & $61 \pm 10.4^{b}$ \\
\hline
\end{tabular}

Means bearing different superscript in the same row are significantly different $(\mathrm{P}<0.05)$.

\section{Light}

The different light regimes tested in the present study had no significant effect over the molt cycle of the prawn $(\mathrm{P}>0.05)$. Prawns kept in complete darkness showed a slightly accelerated molt period of $99 \mathrm{~h}$ (Table 5 ), which was not significant differ (P>0.05) compared to the other light regimes: $12 \mathrm{hL}: 12 \mathrm{hD}$ and $24 \mathrm{hL}: 00 \mathrm{hD}$. Growth increment and survival obtained under different light regimes also did not reveal any significant variations.

Table5: Effects of light on molting, growth and survival of M. rosenbergii larvae (Mean $\pm \mathrm{SD}$ ).

\begin{tabular}{llll}
\hline Parameters & Light (h) & \\
\cline { 2 - 4 } & 24 & 12 & 0 \\
\hline Initial length(cm) & $1.70 \pm 0.255^{\mathrm{a}}$ & $1.70 \pm 0.255^{\mathrm{a}}$ & $1.70 \pm 0.255^{\mathrm{a}}$ \\
Initial weight (g) & $0.04 \pm 0.042^{\mathrm{a}}$ & $0.04 \pm 0.042^{\mathrm{a}}$ & $0.04 \pm 0.042^{\mathrm{a}}$ \\
Final length(cm) & $4.20 \pm 0.313^{\mathrm{a}}$ & $5.10 \pm 1.50^{\mathrm{a}}$ & $4.50 \pm 1.050^{\mathrm{a}}$ \\
Final weight (g) & $0.85 \pm 0.353^{\mathrm{a}}$ & $1.57 \pm 0.44^{\mathrm{a}}$ & $1.43 \pm 0.431^{\mathrm{a}}$ \\
Increase in length (cm) & $2.50 \pm 0.611^{\mathrm{a}}$ & $3.40 \pm 0.778^{\mathrm{a}}$ & $2.80 \pm 0.550^{\mathrm{a}}$ \\
Increase in weight (g) & $0.81 \pm 0.32^{\mathrm{a}}$ & $1.53 \pm 0.398^{\mathrm{a}}$ & $1.39 \pm 0.355^{\mathrm{a}}$ \\
Molt cycle duration (h) & $110 \pm 18.5^{\mathrm{a}}$ & $102 \pm 12^{\mathrm{a}}$ & $99 \pm 16.70^{\mathrm{a}}$ \\
Survival (\%) & $71 \pm 8.8^{\mathrm{a}}$ & $80 \pm 10.7^{\mathrm{a}}$ & $77 \pm 9.95^{\mathrm{a}}$ \\
& & & \\
\hline
\end{tabular}

Means bearing different superscript in the same row are significantly different $(\mathrm{P}<0.05)$. 


\section{DISCUSSION}

\section{Temperature}

Temperature is one of the important environmental factors directly affects the molt cycle and growth of $M$. rosenbergii. Molting frequency increased (decreased molt cycle duration) with corresponding increase in temperature. But the relationship was not linear in terms of the tissue growth of the animal (Vijayan and Diwan, 1995). In the present study a coordinated increase of molting frequency and tissue growth was noted only up to $30{ }^{\circ} \mathrm{C}$. Beyond this temperature, no corresponding tissue growth was recorded although the molt cycle duration was reduced. Highest survival was observed for group of prawns exposed to 25 and $30{ }^{\circ} \mathrm{C}$, while the lowest survival was recorded at $35{ }^{\circ} \mathrm{C}$. Present observations agrees with ( Verhoef and Austin 1999) who observed a relationship between water temperature and survival of Cherax destructor, as temperature increase the survival rate increase until an optimum temperature, there after, survival rates declined towards the upper temperature range within which the species can survive. Also the present data similar to that obtained by Hewitt and Duncan (2001) who reported that mortality was highest at $36^{\circ} \mathrm{C}$ and equally lowest between 28 and $32^{\circ} \mathrm{C}$. Intermolt period and growth were not significantly different for temperature between 28 and $32{ }^{\circ} \mathrm{C}$, but was significantly greater above $32{ }^{\circ} \mathrm{C}\left(27.4\right.$ days at $34{ }^{\circ} \mathrm{C}$ and 104 days at $\left.36{ }^{\circ} \mathrm{C}\right)$ in Penaeus japonicus. Data herein also confirmed with that obtained by (Vijayan and Diwan 1995) who observed an increase in growth rate over a temperature range of $26-35^{\circ} \mathrm{C}$, and a precipitous drop at $35{ }^{\circ} \mathrm{C}$ in Penaeus indicus. Reduced growth of $P$. serratus in low as well as high temperature was reported by Richared (1978). According to Canan (1985), in crustaceans, within a specific temperature range, intervals between ecdysis are usually shortened with a corresponding increase in tissue growth until a threshold level of temperature is reached. Beyond this threshold temperature, mortality become rather erratic. This is true in the case of $M$. rosenbergii where the temperature threshold was up to $30^{\circ} \mathrm{C}$. Above this temperature, significant tissue growth was not achieved despite a shortened molt cycle. The differential effect of temperature on growth might be due to its direct effect on body metabolism mediated though endocrine secretions (Aiken and Waddy, 1975) or by rate of feeding. In this study the optimum temperature for molting, growth and survival of $M$. rosenbergii recorded was $30^{\circ} \mathrm{C}$.

\section{Salinity}

Salinity is one of the key factors for aquatic crustacean species and can effect spawning, growth and survival rates Hazel et al. ( 2005). El- Sayed (1997) reported that salinity has significantly affected growth performance and mortality rates of $M$. rosenbergii. In the present study, molting, growth and survival of $M$. rosenbergii larvae were significantly influenced by varying levels of salinity. M. rosenbergii exposed to higher salinities ( 15 ppt salinity ) had lower growth rates and suffered from muscle necrosis. This are in 
agreement with that obtained by Lakshmi et al. (1978) who observed muscle necrosis in Penaeus aztecus exposed to sub-optimal and supra-optimal salinity ranges. They describe the development of muscle necrosis as an indication of stress on the animal. The present results were in agreement with El-Sayed (1997) who concluded that growth rate, food efficiency and mortality of $M$. rosenbergii decreased with increasing water salinity beyond 6 ppt. However, (Normant and Lamprecht 2006) indicated that increasing salinity was accompanied by a reduction in the metabolic rate of the amphipod, Gammarus oceanicus and the greatest values for scope for growth at salinity $7 \mathrm{psu}$. The present results support the observation of ( Ling and Costello 1976) who indicate that brackish waters up to about $10 \mathrm{ppt}$ are suitable for farming $M$. rosenbergii. In this respect, Huong et al. (2010) studied the effect of different salinity levels (0, 15 or $25 \%$ o salinity) on growth and molting of $M$. rosenbergii and found that the weight gain in $0 \%$ and $15 \%$ were not significantly different after 4 months rearing period. And the 25\% group suffered from low growth, high mortality and significantly lower molting frequency. They recorded that this species can be reared in brackish water up to $15 \%$ salinity.

Earlier laboratory studies, indicated that juveniles freshwater prawns molt and grow more rapidly in freshwater or slightly brackish water $(<5 \mathrm{ppt})$ when compared to more brackish water up to 15 ppt (Goodwin and Hanson, 1975; Perdue and Nakamura, 1976) these studies were in line with the present one.

For some marine shrimp, Huang (1983) concluded that Penaeus vannamei grew best at about 20\%o and observed poorest results at 5 and 45\%. For brown shrimp, Farfantepenaeus californiesis, reduced growth rate was associated with increased salinity and this may be related to reduced feed consumption associated with increased salinity. The present observations show that $M$. rosenbergii can survive in all salinities tested, but best growth takes place only at $5 \mathrm{ppt}$ salinity followed by zero salinity. Above this range cycle duration increase, growth increment, survival gradually decrease with increasing salinity.

\section{The $\mathbf{p H}$ values}

Hydrogen ion is one of the important water quality parameters for fisheries. The optimum $\mathrm{pH}$ value for freshwater animals is normally between 6.5 and 8.5 (Alabaster and Lioyd, 1980), while the optimum value recommended for marine aquaculture is between 7.5 and 8.5 Law(1988). (Vlijayan and Diwan 1995) stated that the $\mathrm{pH}$ was found to have a direct effect over the molting process of Penaeus indicus. In the present study, both lower (acidic, $6 \pm 0.3$ ) and higher (alkaline 9 \pm 0.3 ) $\mathrm{pH}$ were limiting factors for the process of molting, growth and survival of $M$. rosenbergii. Low $\mathrm{pH}$ is reported to be harmful to crustaceans (Havas and Hutchinson, 1982). In line with the present study, (Allan and Maguire 1992) recorded depressed growth of Penaeus monodon and P. occidentalis in $\mathrm{pH} 5.5$ and 4.9 compared with those grown in $\mathrm{pH}$ 7.8. Wickins (1984) reported that the 
growth of P. monodon was reduced when $\mathrm{pH}$ was lowered to $\mathrm{pH} 6.4$ and the sub-optimal $\mathrm{pH}$ in the acidic range adversely affected body mineralization in the prawn. (Chen and Chen 2003) reported that after 56 days of exposure , M. rosenbergii juveniles placed in pH 6.8 exhibited significantly lower molting frequency, feeding rate and body weight gain, this confirm the present study. In thist investigation lower survival was observed at lower $\mathrm{pH}, 6$. In this respect Pillai et al. (1978) reported the mass mortality of crustaceans in Vembanad lake due to low $\mathrm{pH}$. The present study clearly indicated that an optimum $\mathrm{pH}$ of 7-8 provides ideal conditions for successful molting, best growth and survival of $M$. rosenbergii. Outside this optimum range, both higher and lower $\mathrm{pH}$ adversely affected growth rate.

\section{Light}

The influence of light-dark regimes in this investigation did not show any significant effect on molting duration, growth or survival rates of prawns. Skinner and Graham (1974) noticed precocious molting in animals kept in darkness when compared with those exposed to light. But they attributed the effect to privacy rather than to amount of exposure to darkness. In the present case, the slightly accelerated molt period among the prawns under complete darkness was not significant. The effect of photoperiod in crustacean growth is generally inconclusive and contradictory in nature (Vljayan and Diwan 1995). Forster and Bread (1973) reported enhanced growth in Palaemon serratus; while Chittleborough (1975) reported inhibition of growth in darkness in Panulirus longipus. Observation of Juto et al. (1991) and Vljayan and Diwan (1995) agree with the current study that molting and growth of prawns would not be affected by changes in photoperiod. It is worth mentioning that, in extreme levels of temperature, salinity and $\mathrm{pH}$, prawns appeared lethargic with poor feed intake. Hence, in semi-intensive farming conditions, when shrimp farms face extreme conditions of temperature, salinity and $\mathrm{pH}$, farmers may reduce feeding rate to prevent feed wastage and spoilage in pond water.

\section{Conclusion}

The current study showed that the best growth performance of the freshwater prawn, Macrobrachium rosenbergii was achieved at the optimum conditions of temperature, $30^{\circ} \mathrm{C}$, salinity of $5 \mathrm{ppt}, \mathrm{pH}$ of 8 . While light regimes showed no significant differences. Outside the optimum conditions, prawns survive but with low growth rate. The concept that" more molting means more growth in prawn is true only in the optimum levels of environmental variables. Otherwise, increase in molting frequency did not necessary enhance growth rate. 


\section{REFERENCES}

Aiken, D.E. ( 1980). Moulting and growth In: The biology and management of lobsters, Vol. 11 (eds. J.S. Cobb and B.F. Phillips), pp. 91-163. Academic Press, New York.

Aiken, D.E. and Waddy, S.L. (1975). Temperature increase can cause hyperecdysonism in American lobsters (Homarus americanus) injected with ecdysterone. Journal of the Fisheries Research Board of Canada 32: 18431845.

Alabaster, J.S. and Lioyd, R. (1980). Water quality Criteria for freshwater Fish Butterworths. London. 297 pp.

Allan, G.L. and Maguire, G.B.(1992). Effect of pH and salinity on survival, growth and osmoregylation in Penaeus monodon Fabricus. Aquaculture 107: 33-47.

Boyd, C.E. (1990). Environmental requirement In:" water quality in ponds for aquaculture" (ed. C.E. Boyd,pp. 131-169, Birmingham publishing, Co., Birmingham.

Canan, G.Y. (1985). Periodically and phasing of moulting In: Crustaceans issues, (ed. A.M. Wenner), pp. 73-99. A.A. Balkema, Brookfield Publishing Co., UK.

Chen, J.C. and Kou, C.T. (1996). Nitrogen excretion in Macrobrachium rosenbergii at different pH levels. Aquaculture. 144: 155-164.

Chen, S-M. and Chen, J-C. (2003). "Effect of pH on survival, growth, molting and

feeding of giant freshwater prawn Macrobrachium rosenbergii". Aquaculture. 218: 613-623.

Chittleborough, R.G. (1975). Environmental factors affecting growth and survival of juvenile western rock lobster, Panilurus logipes . Australian Journal of Marine and freshwater Research. 26: 177-196.

Dall, W.; Hill, B.J.; Rothilsberg, P.G. and Staples, D.J. (1990).The Biology of

Penaeidae. Advances in Marine Biology. 27: 1=XIII: 1-489.

El-Sayed, A. M. (1997).“The Response of freshwater Prawn Macrobrachium rosenbergii to Different Levels of Freshwater Hardness and Salinity". 7thInternational

Conference on Environment Protection is a Must, 20-22, Alex., Egypt, Organized by N.I.O.F.

Forster, J.R.M. and Beard, T.W.(1973). Growth experiments with the prawn, Palaemon serratus. Britsh Ministry of Agriculture and Fisheries Investigation Series 11, 27: 1-16.

Goodwin, H.L. and Hanson, J.A.(1975). The aquaculture of freshwater prawns (Macrobrachium species). Augmented summary of Proceedings of the Workshop on culture of freshwater prawns. St. Petersburg, Florida. The Oceanic Institute, Walmanalo, Hawaii. 95 pp. 
Havas, M. and Hutchinson, T.C. (1982). Aquatic invertebrates from the smoking hills. N.WT.: Effect of pH and metals on mortality. Canadian Journal of Fisheries and Aquatic Sciences. 99: 890-903.

Hazel, Matias-Peralta and Fatimah M.d. (2005). Effects of some environmental copepod Nitocra affinis f. califarnica Lang (J)". Marine Pollution Bulletin. 15 (8-12):722-728.

Hewitt, D.R. and Duncan, P.F. (2001). Effect of high wter temperature on the survival, molting and food consumption of Penaeus (Marsupeaeus) japonicus (Bate, 1888). Aquaculture Research. 32: 305-313.

Huang, H.J. (1983). Factors affecting the successful culture of Penaeus vannamei an at estuarine power plant site: temperature, salinity, inherent growth variability, damselfly nymph population density and distribution Ph.D. dissertation. Taxas A\&M University College station. TX. USA, 221 pp.

Huong, D.T.; Wang, T.; Bayley, M.and Phuong, N.T.(2010). Osmoregulation, growth and moulting cycles of the giant freshwater prawn (Macrobrachium rosenbergii) at different salinities. Aquaculture Research. 41(9): 135-143.

Justo, C. ; Aida, K. and Hanyu, I. (1991). Effect of photoperiod and temperature on moulting, reproduction and growth of the freshwater prawn, Macrobrachium rosenbergii. Nippon Suisan Gakkaishi. 57: 209-217.

Lakshmi, G.J.; Venkatarramiah, A. and Howse, H.D. (1978). Effect of salinity and temperature changes on spontaneous muscle necrosis in Penaeus aztecus. Aquaculture. 13: 35-43.

Law, A.T. (1988). Water quality requirement for Penaeus monodon culture. In: Singh, T. Ang, K.J.(Eds.) Marine prawn, Farming in Malaysia: Present Problem Future Prospects. The Malaysian Fisheries Society Ocassional Publication. Vol. 1, pp. 53-65.

Ling, S.W. and Costello, T.J. (1976). Status and problems of Macrobrachium farming in Asia. Proceedings Food-Drugs from the sea conference. Mayaguez Puerto Rico. 1974 (Marine Technology Society).pp. 66-71.

New, M.B. (1995). Status of freshwater prawn farming: a review. Aquaculture Research. 26:1-54.

Normant, M. and Lamprecht, I. (2006). Does scope for growth change as a result of salinity stress in the amphipod Gammarus oceanicus! Journal of Experimental Marine Biology and Ecology. 334: 158-163.

Perdue, J.A. and Nakamura, R. (1976). The effect of salinity on the growth of Macrobrachium rosenbergii. Proceedings World Mariculture Society. 7: 647654.

Pillai, V.K.; Ponnaih, A.G.; Vincent, D. and Davidraj, I. (1978). Acidity in Vembanad lake causes mortality. Marine Fisheries Information Service Technical and Extension Series. 53: 8-15. 
Richard, P. (1978). Effect of temperature on the growth and molting of Palaemon serratus in relation to their size. Aquaculture. 14: 13-22.

Skinner, D.M. and Graham, D.E. (1974). Loss of limb as a stimulus to ecdysis in Brachyura. Biolgical Bulletin, 79: 145-152.

Venkitraman, P.R. ; Jayalakshmy, K.V. and Balasubramanian, T. (2010). Effect of eyestalk ablation on molting and growth in panaeid prawns: Metapenaeus monoceros. Indian J. Fish 57(2): 25-32.

Verhoef, G.D. and Austin, C.M. (1999). Combined effects of temperature and density on the growth and survival of juveniles of the Australian freshwater crayfish, Cherax destructor Clark, Part 1. Aquaculture. 170: 37-47.

Vlijayan, K.K. and Diwan, A.D. (1995). Influence of temperature, salinity, pH and light on molting and growth in the Indian white prawn Penaeus indicus (Crustacea:Decapoda: Penaeidae) under laboratory conditions. Asian Fisheries Science. 8: 63-72.

Wickins, J.F. (1984). The effect of reduced pH on carapace calcium, strontium, and magnesium levels in rapidly growing prawns (Penaeus monodon). Aquaculture. 41: 49-60.

Zar, J.H. (1984). Biostatistical analysis, 2nd Edition. Prentice-Hall International Inc., New Jersey. 